\title{
Membrane translocation of penetratin and its derivatives in different cell lines
}

\author{
T. Letoha, ${ }^{1}$ S. Gaál, ${ }^{1}$ C. Somlai, ${ }^{1}$ A. Czajlik, ${ }^{2}$ A. Perczel $^{2}$ and B. Penke ${ }^{1 *}$ \\ ${ }^{1}$ Department of Medical Chemistry, University of Szeged, Szeged, Hungary \\ ${ }^{2}$ Department of Organic Chemistry, Eötvös Lorand University, Budapest, Hungary
}

\begin{abstract}
The third helix of the homeodomain of the Antennapedia homeoprotein can translocate through the cell membrane into the nucleus and can be used as an intracellular vehicle for the delivery of oligopeptides and oligonucleotides. A 16-amino acid-long peptide fragment, called penetratin, is internalized by the cells in a specific, non-receptor-mediated manner. For a better understanding of the mechanism of the transfer, penetratin and two analogs were synthesized:
\end{abstract}

(1) penetratin

(2) (6,14-Phe)-penetratin,

(3) dodecapeptide,

\section{RQIKIWFQNRRMKWKK (peptide 1); RQIKIFFQNRRMKFKK (peptide 2); RQIKIWF-R-KWKK (peptide 3);}

The conformation of penetratin peptides 1-3 was examined in both extracellular matrix-mimetic and membrane-mimetic environments. ${ }^{1} \mathrm{H}-\mathrm{NMR}$ and CD spectroscopic measurements were performed in mixtures of TFE/water with different ratios. Peptides 1-3 were labeled by reacting their N-terminal free amino group with fluorescein isothiocyanate (FITC). Membrane translocation of the labelled peptides was studied with cell cultures [WEHI 164 murine fibrosarcoma cells (WC/1); chicken fibroblast cells (CEC-32); chicken monocytic cells (HD-11); human fibroblast (SV 80) and human monocytic cells (MonoMac-6)]. Confocal laser scanning microscopy and flow cytometry assay were used to study membrane translocation. Amphiphilicity was calculated for each peptide. In our experiments all the penetratin peptides penetrated into the cells. Helical conformation and membrane translocation ability showed little correlation: substitution of the two Trp with Phe increased the stability of helical conformation but decreased membrane translocation activity. The results of fluorescence microscopy and flow cytometry show that penetratin can be translocated into the cells by two mechanisms: endocytosis and direct transport through the cell membrane. Copyright (C) 2003 John Wiley \& Sons, Ltd.

Keywords: cell penetrating peptides; penetratin; NMR; CD; conformation; FITC-labeling; translocation mechanism; amphiphilicity

Received 25 April 2003; revised 6 June 2003; accepted 13 June 2003

\section{INTRODUCTION}

Many therapeutic agents (drugs, oligonucleotides, polypeptides) act at intracellular sites. Their biological efficacy depends on an efficient delivery into the target cell. Charged and large compounds cannot penetrate through lipid membranes and require active transport mechanisms for uptake into cells. A series of delivery systems (viral vectors, cationic lipids, liposomes, controlled-release polymers) has been used for translocation of hydrophilic therapeutic agents through the membranes.

Cell penetrating peptides (CPPs) are one of the most widely used delivery systems. This group of compounds is very heterogeneous and has only one common denominator: these peptide vectors translocate through the cell membrane and can transport cargo molecules, covalently bound, into

*Correspondence to: B. Penke, 6720 Szeged, Dóm tér 8., Hungary.

E-mail: penke@ovrisc.mdche.u-szeged.hu

Abbreviations used: CPP, cell penetrating peptide; FACS, fluorescenceactivated cell sorter; FITC, fluoresceine isothiocyanate; FTC, fluoresceinthiocarbamoyl. the cell. The simplest peptides are short arginine-rich sequences (Tat 49-57: Vives et al., 1997) and oligoarginines (Rothbard et al., 2000; Futaki et al., 2001; Suzuki et al., 2002) that exhibit efficient intracellular import properties. Peptidomimetics such as oligoguanidine peptide derivatives (Wender et al., 2000) are also effective CPPs. Hydrophobic sequences can also serve as import signals for crossing the membrane (Lin et al., 1995; Zhang et al., 1998; Morris et al., 1999; Guiochon-Mantel et al., 1994). Branched peptides with defined structure (loligomers) are non-natural peptidebased vehicles for drug delivery (Gariépy and Kawamura, 2001; Sheldon et al., 1995).

Amphipatic peptides with cationic character form the most interesting group of CPPs. Transportan, a hybrid peptide of galanin and mastoparan (Pooga et al., 2001) has been widely used as a drug delivery vector. Synthetic amphipatic model peptides like KLALKLALKALKAALKLA proved to have good membrane translocation properties (Oehlke et al., 1997, 1998; Scheller et al., 1999). Recent advances in the field of cell penetrating peptides have been reviewed (Lindgren et al., 2000; Plank et al., 1998; Bogoyevitch et al., 2002; Garcia-Chaumont 
et al., 2000; Gariépy and Kawamura, 2001; Morris et al., 1999; Singh et al., 1999; Fischer et al., 2001; Langel, 2002).

Penetratin, a synthetic 16-amino acid peptide from the third helix of Antennapedia homeodomain (Derossi et al., 1994, 1996, 1998; Fischer et al., 2000) is a cationic, amphipatic peptide and might penetrate cell membrane via a postulated 'inverted micelle' pathway. However, the mechanism of membrane translocation is not well known. The main question is whether the peptide is internalized via endocytosis which is energy-dependent, or via direct transport? While the latter mechanism is largely unknown at present, it is believed to be a non-receptor-mediated process (Drin et al., 2001; Derossi et al., 1996).

Penetratin has been proposed as a universal intracellular delivery vehicle (Dupont et al., 2002). A comprehensive analysis led to the conclusion that all three aromatic residues, two Trp (6 and 14) and one Phe (7) play crucial roles in the penetration process (Derossi et al., 1994). A penetratin analogue containing only D-amino acids (D-penetratin) proved also to be an efficient vector (Rousselle et al., 2000).

In order to examine the correlation between chemical structure and membrane translocation activity, penetratin and two analogs with the following structures were synthesized:
(1) penetratin
(2) $(6,14-\mathrm{Phe})$
RQIKIWFQNRRMKWKK (peptide 1); -penetratin,
(3) dodecapeptide, RQIKIWF-R-KWKK （peptide 3);

In peptide 2 the Trp-residues were replaced by Phe for investigating the effect of different aromatic side chains on the membrane translocation of the peptide. A third, shorter, biologically effective peptide (peptide 3 ) was also designed, in which two pairs of residues $\left(\mathrm{Q}^{8}-\mathrm{N}^{9}\right.$ and $\left.\mathrm{R}^{11}-\mathrm{M}^{12}\right)$ were simultaneously removed from the central turn of the helix. The consideration, that a peptide-based delivery vector should be as short as possible in order to reduce cost, guided the synthesis of this dodecapeptide. The conformation of the peptides was studied by ${ }^{1} \mathrm{H}-\mathrm{NMR}$ and $\mathrm{CD}$ spectroscopy. Bioassay was performed using different cell lines. FITClabeled derivatives of the three penetratin peptides were also synthesized for studying the membrane translocation using confocal microscopy.

\section{NMR AND CD-STUDIES OF PENETRATIN PEPTIDES}

NMR spectra were typically recorded at $500 \mathrm{MHz}$ (Bruker Instruments) and were processed with the Insight II-Felix97 software package. Structure determination was performed in TFE $d_{2} /$ water $=9: 1$. Homonuclear COSY and TOCSY spectra were used for identification of the spin systems. An atomic level comprehensive analysis of penetratin and its two analogues was performed (Czajlik et al., 2002). Increase of the polarity of the molecular environment
A

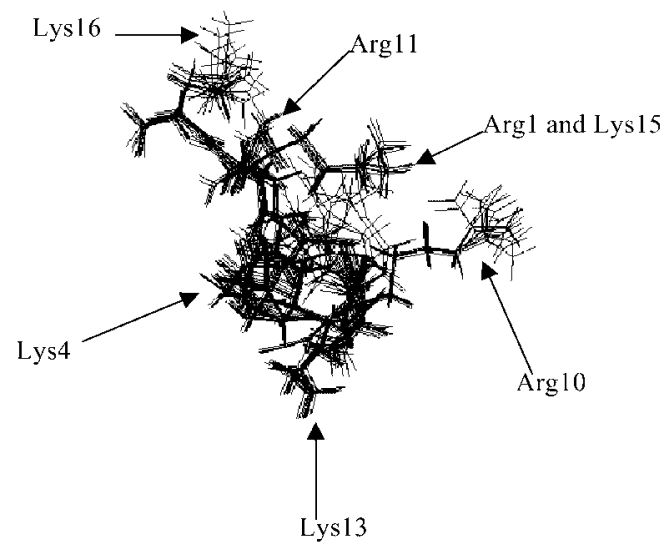

C

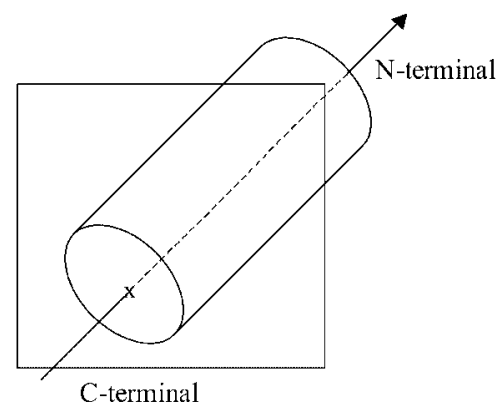

B

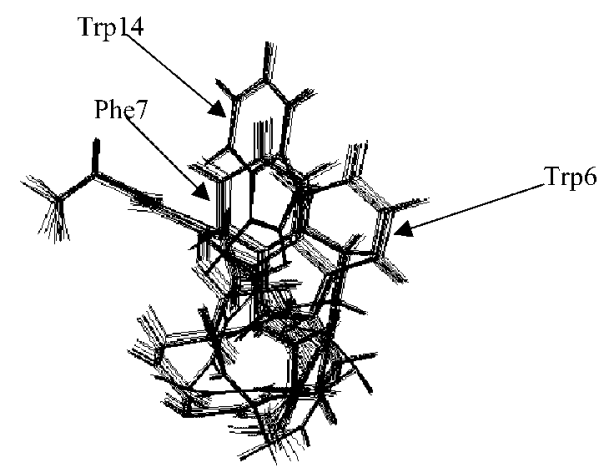

Figure 1. The best 10 structures of penetratin from the plane of the helix, superimposed on the heavy atoms of residues 1-16 in TFE-water 9:1 system. The packing of basic side chains $(A)$ and the aromatic side chains (B); the approximate orientation of the helical cylinder $(\mathrm{C})$. 

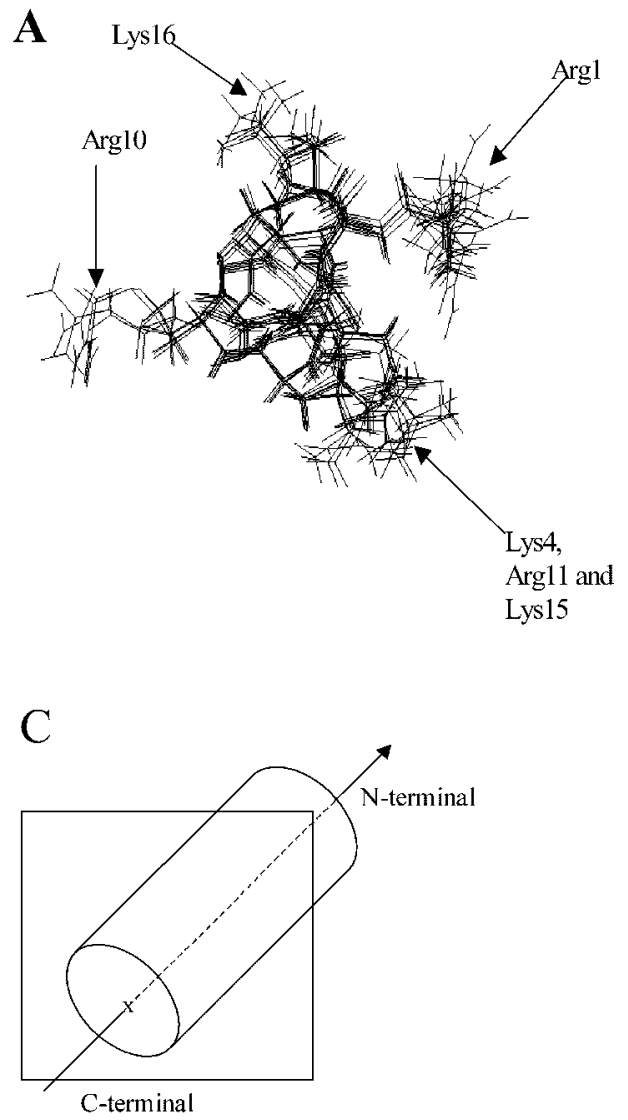

B

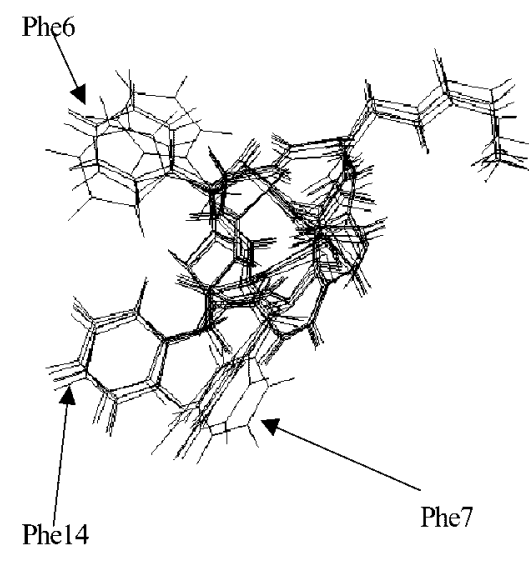

Figure 2. The best structures $(6,14-\mathrm{Phe})$-penetratin from the plane of the helix, superimposed on the heavy atoms of residues 1-16. The packing of basic side chains $(A)$ is on the left and the aromatic side chains $(B)$ is on the right; the approximate orientation of the helical cylinder (C).

was performed up to highly aqueous system (TFE $\mathrm{d}_{2} /$ water $=1: 9)$.

CD spectra were recorded on a Jobin Yvon dicrograph Mark IV. Typically, three scans were acquired with a cell path length of $0.02 \mathrm{~cm}$, between 185 and $280 \mathrm{~nm}$. CD data were analysed via the recently updated version of Convex Constraint Analysis Plus (CCA + ).

\section{Peptide structure in highly aqueous medium}

$\mathrm{CD}$ results have shown that penetratin has a considerable population of non-random structures $(\sim 40 \%)$, even in aqueous solution. The NOESY spectra of the penetratin indicate a threshold population with ordered structures. Locally ordered structural segments are present in the molecule and short-range order can be traced: the peptide assumes a nascent helical conformation (Dyson et al., 1988).

The penetratin analogues (peptides 2 and 3 ) exhibited multiple structures unresolved at the NMR timescale. This conclusion is supported by CD-data.

\section{Peptide structure in a low dielectric environment}

The conformation of penetratin involves a helix-like structure in the $4-12$ region, which begins and ends with a $\beta$-turn.
The aromatic rings of the Trp and Phe in positions 6 and 7 are close to each other (Fig. 1). The aromatic side chains, together with the two Ile in positions 3 and 5, form a hydrophobic core. The molecule is stabilized by interactions between the hydrophobic amino acids and by multiple hydrogen bonds. Penetratin can only be described in a hydrophobic environment by one well-defined conformation corresponding to a bent helical structure in the 4-12 region. Our data show that penetratin is a non-ideal helix which looks like a 310 helix with $\beta$-turns at the two ends.

The (6,14-Phe)-penetratin (peptide 2) adopts a helical structure, interrupted by a $\beta$-turn (Fig. 2). Both the 3-9 and 12-14 regions display helical properties on the basis of dihedral angles.

The dodecapeptide (peptide 3 ) has a helical conformation only in the central region including residues 5-9 (Fig. 3). The peptide does not form a hydrophobic core. Since this peptide is very short, the molecule cannot be described by a single well-determined structure, and is characterized by several somewhat similar conformers.

\section{Structure of penetratin peptides based on CD-spectra}

CD-spectroscopy is sensitive to small conformational changes in molecules. For the three penetratin peptides, a 
A

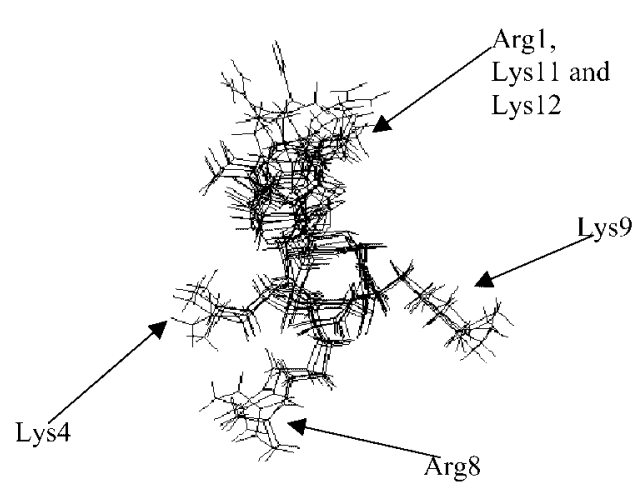

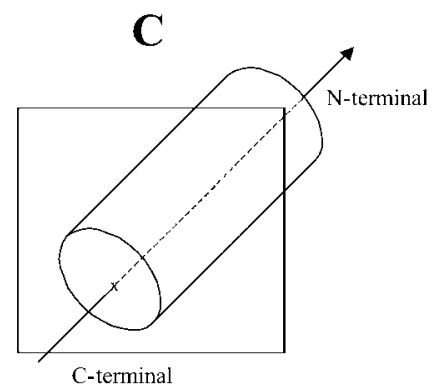

B

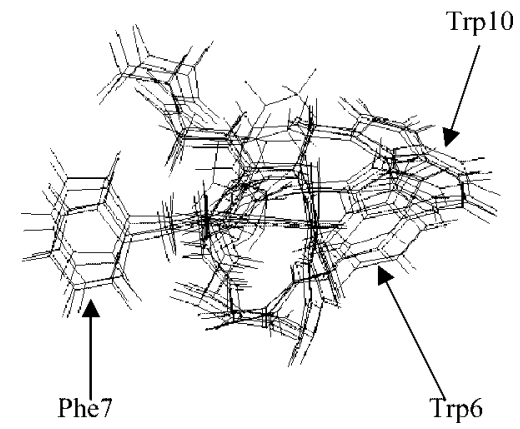

Figure 3. The best 10 structures of penetratin dodecapeptide from the plane of the helix, superimposed on the heavy atoms of residues 1-12. The packing of basic side chains $(A)$ is on the left and the aromatic side chains $(B)$ is on the right; the approximate orientation of the helical cylinder (C) is in the middle.

total of $21 \mathrm{CD}$-curves were acquired at TFE percentages of $0,10,25,50,75,90,94$ and $100 \%$. One representative CDspectrum of penetratin is shown in Fig. 4.

For all three peptide models, an increase of the TFE concentration in water, clearly increases the helical and/or $\beta$-turn content and decreases the atypical or random part of the backbone conformation. In pure TFE, the structures of both penetratin and peptide 3 (dodecapeptide) appear to be assemblies of type I and III $\beta$-turns, while the conformation of $(6,14-\mathrm{Phe})$ penetratin is more like that of an $\alpha$-helix. The backbone structure of penetratin peptides is shown in Fig. 5.

\section{Study of penetration of penetratin-peptides into different cell types}

Penetratin and the two model peptides were fluorescently labeled for studying their penetration into cells. FITC was used for labeling the N-terminal amino group of the peptide

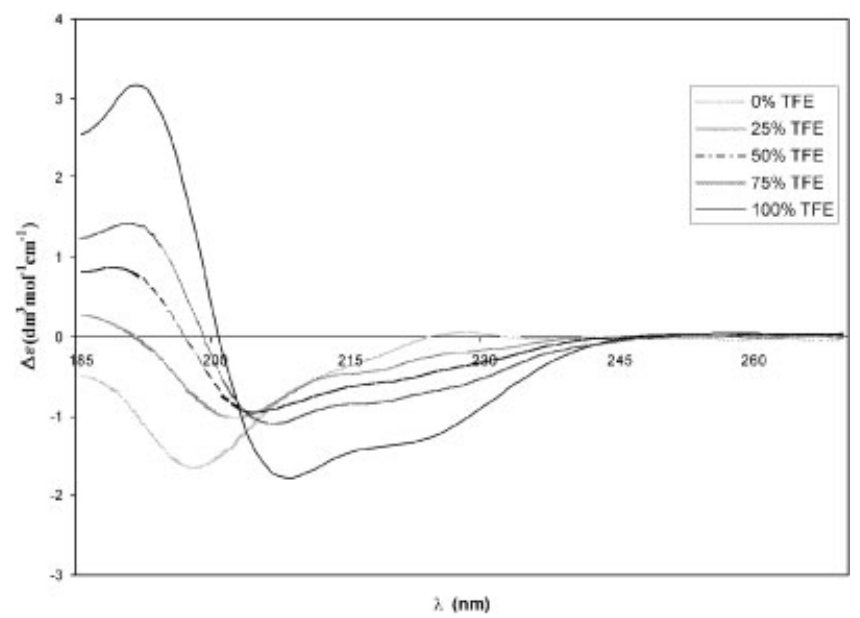

Figure 4. CD spectra of penetratin recorded in different TFEwater systems. resulting in fluorescein-thiocarbamoyl (FTC) peptide derivatives. Membrane translocation of FTC-penetratins was studied by confocal fluorescence microscopy on living cells using the following cell lines: chicken monocytic cells (HD11), human fibroblasts (SV-80), HeLa cells and L929 murine fibroblast cells. For quantitative measurement of peptide translocation fluorescence activated cell sorter (FACS) measurements were used on L-929, SV-80, human monocytic (MonoMac 6), chicken fibroblast (CEC-32) and WEHI 164 murine fibrosarcoma (WC/1) cells. Temperature dependence of the uptake kinetics of FTC-penetratin was also studied on SV 80 cells at 37,20 and $4^{\circ} \mathrm{C}$ using FTCpentaglycine as negative control. The following results were obtained:

(1) FTC-penetratin enters the cell in a relatively short time (30-60 $\mathrm{min})$ and will be concentrated in the cell nucleus in $90 \mathrm{~min}$ (Fig. 6).

(2) The membrane translocation is temperature-dependent. Using SV-80 cells, FTC-penetratin shows practically no translocation activity at $4^{\circ} \mathrm{C}$. At $20^{\circ} \mathrm{C}$ penetration is a very slow process. FTC-pentaglycine not can penetrate into SV-80 cells. At $37^{\circ} \mathrm{C}$, FTC-penetratin translocates rapidly into the cells and concentration in the cells is time-dependent (Fig. 7). Lack of peptide penetration at low temperature is interpreted in the literature as proof of an active, energy-dependent transport mechanism. We believe that this interpretation is incorrect since at 0 or $4^{\circ} \mathrm{C}$ mammalian cell membranes are rigid corresponding to a frozen state! This allows no direct translocation via physicochemical interaction between peptide vectors and membranes. Therefore the lack of peptide translocation at 0 or $4{ }^{\circ} \mathrm{C}$ in mammalian cell cultures cannot be taken as evidence for an energydependent transport mechanism.

(3) Cell membrane fluidity affects the translocational activity of penetratin (Fig. 8). Cell lines with different membrane fluidity were incubated with FTC-penetratin and FTC-pentaglycine. Translocation was measured at 


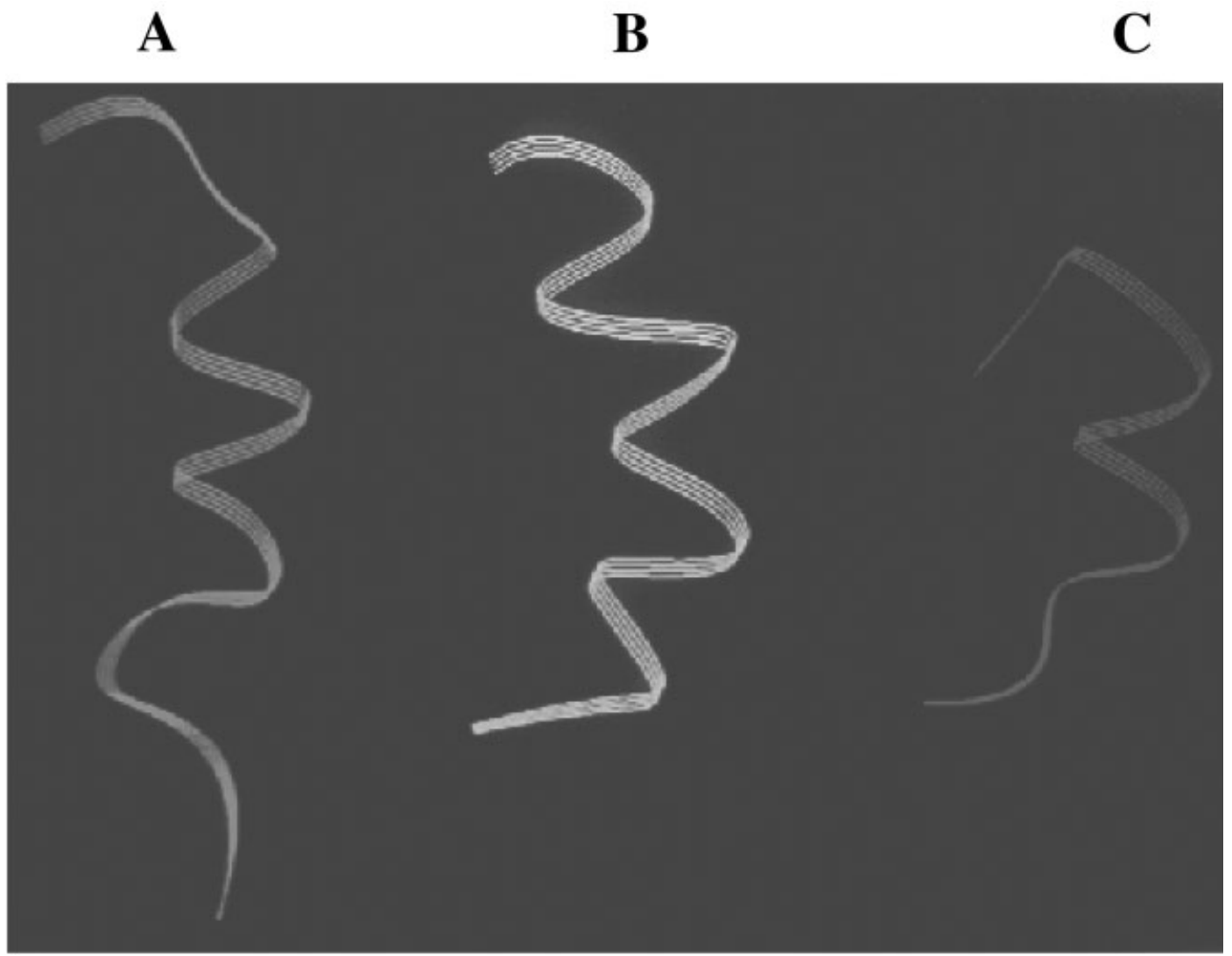

Figure 5. The backbone structure of penetratin (A), (6,14-Phe)-penetratin (B), and the shorter dodecapeptide (C).

$37^{\circ} \mathrm{C}$ after $60 \mathrm{~min}$. One of the cell types used $(\mathrm{WC} / 1$ cells) possesses a gene which gives the cell membrane a high fluidity. Figure 8 shows that penetratin translocates very rapidly and effectively also in these cells. High membrane fluidity increases peptide translocation.

(4) Peptide structure strongly influences the translocation activity. Figure 9 shows the peptide uptake of different cell lines at 37 and $0^{\circ} \mathrm{C}$, using quantitative flow cytometry measurements. FTC-pentaglycine shows practically no translocation into any cells at any temperature. The (6,14-Phe) penetratin analog enters the different cell types very slowly. Interestingly, the short penetratin dodecapeptide is almost as active in membrane translocation as the mother compound. High membrane fluidity enhances penetration of all the peptides. The most interesting feature is the behaviour of MonoMac cells that
A
B

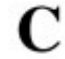

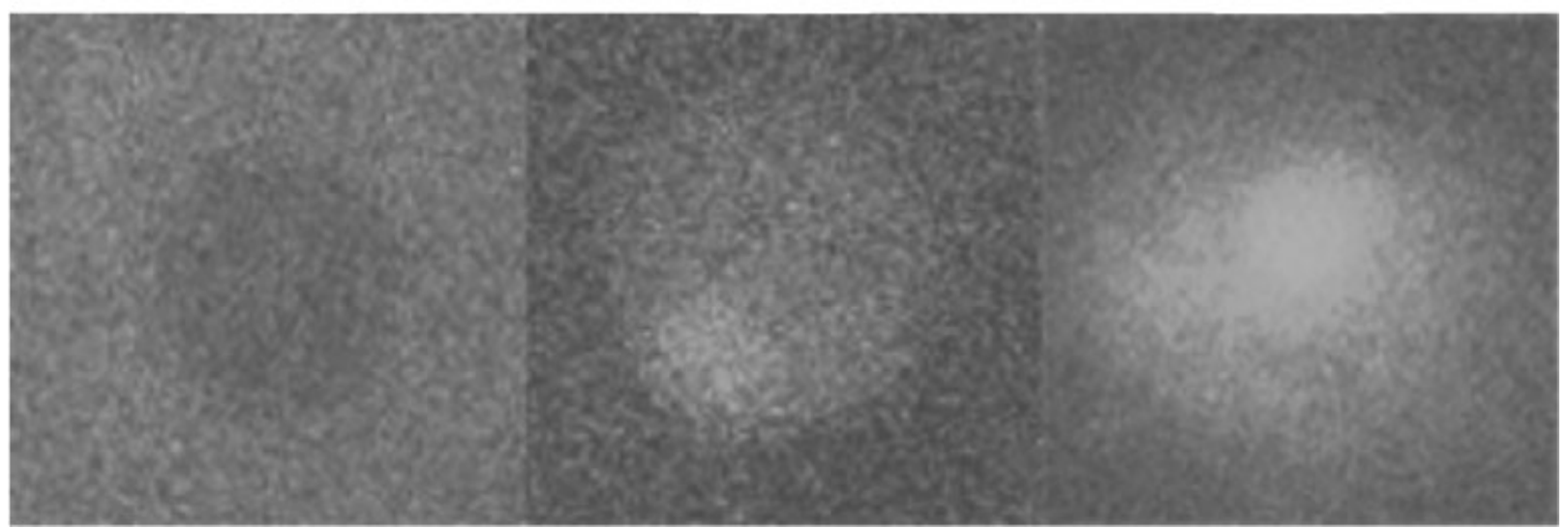

Figure 6. Peptide visualization by confocal microscopy. HeLa cells were incubated with FTC-penetratin for 30 (A), 60 (B) and 90 (C) $\min$ at $20^{\circ} \mathrm{C}$. 

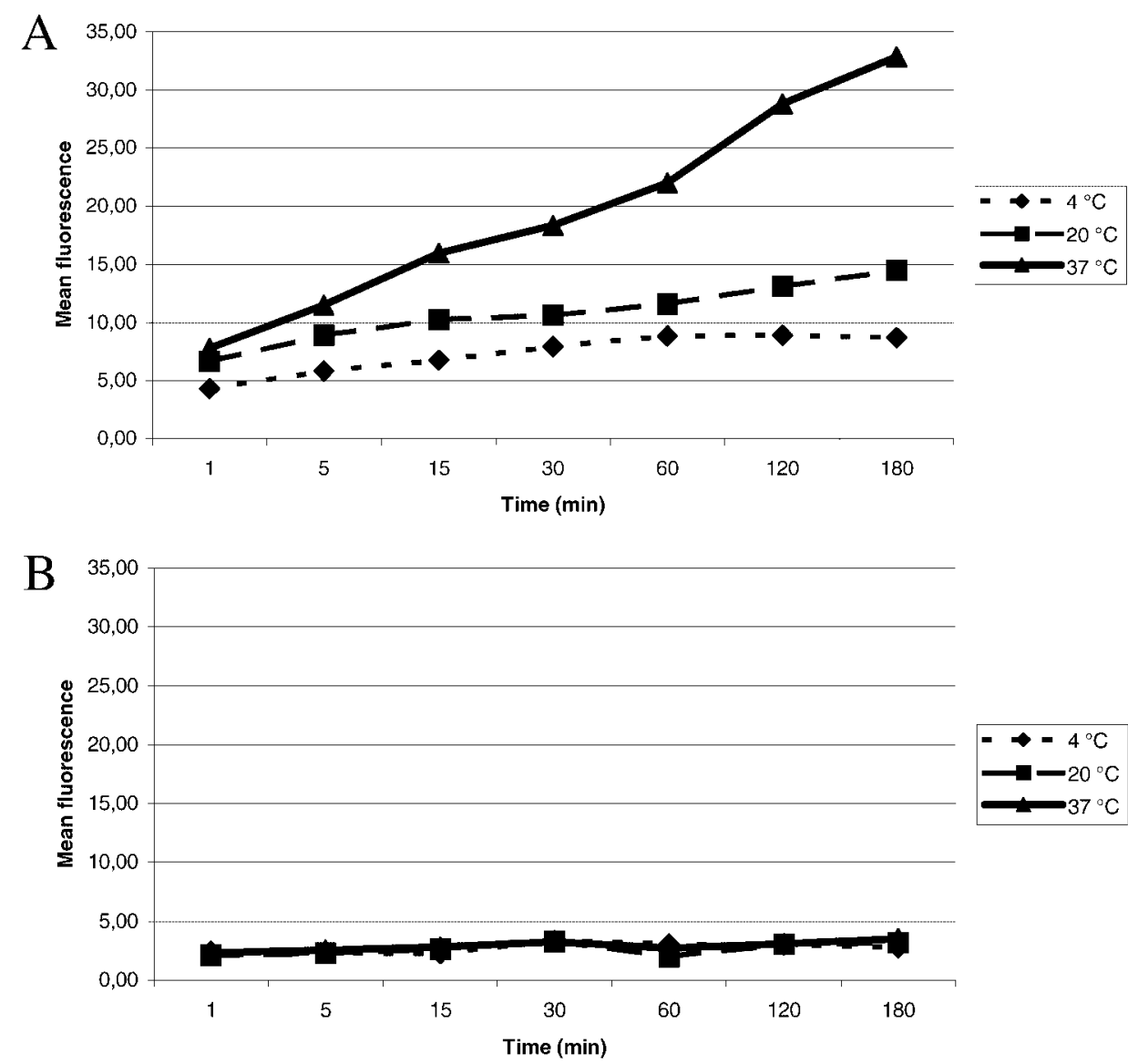

Figure 7. Temperature dependence of the uptake kinetics of FTC-penetratin. SV80 cells were incubated at 37,20 and $4^{\circ} \mathrm{C}$, respectively, with FTC-penetratin (A) and FTC-pentaglycine (B) at a concentration of $1 \mu \mathrm{M}$ for various periods of time $(1,5,15,30,60,120$ and $180 \mathrm{~min})$.

possess high endocytotic capacity: these cells show the highest cellular uptake of penetratin and its analogues.

\section{DISCUSSION AND CONCLUSION}

Internalization of peptide vectors has been investigated by a chemical approach. A well-known hypothesis states that tilted peptides can destabilize membranes (Brasseur, 2000). Conformational and topological requirements of cellpermeable peptide functions have been studied (Burton

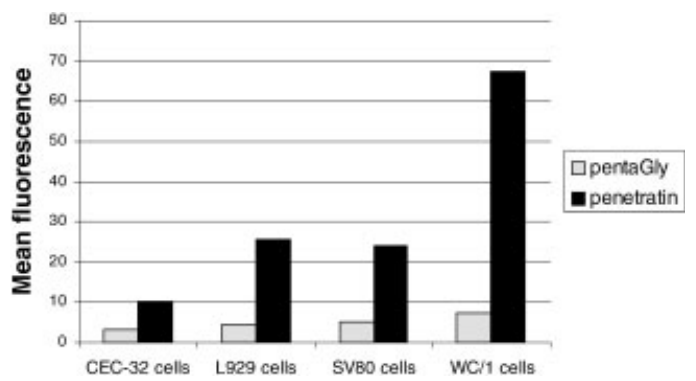

Figure 8. The effect of membrane fluidity on the translocational activity of penetratin. CEC-32, L929, SV80 and WC/1 cells were incubated with $1 \mu \mathrm{M}$ of FTC-penetratin and pentaglycine at $37^{\circ} \mathrm{C}$ for $60 \mathrm{~min}$. et al., 1996; Du et al., 1998). Cargo delivery kinetics of CPPs were also measured (Hällbrink et al., 2001). Peptidelipid interactions were studied (Magzoub et al., 2001) also by penetratin (Persson et al., 2001). Translocation of penetratin through artificial lipid bilayers was directly observed (Thorén et al., 2000) and the position of the peptide in SDS micelles was determined by NMR (Lindberg and Gräslund, 2001). Conformational and associative behaviors of penetratin in membrane-mimetic environments (Berlose et al., 1996) led to the hypothesis that penetratin forms inverted micelles in which the peptide is trapped (Dupont et al., 2002). In this model, penetratin is always kept in hydrophilic environment, included in the cavity of the micelle. Peptide helicity seems to be not important for the translocation (Derossi et al., 1996). This hypothetic mechanism favors a direct transport of penetratin which is fully receptor independent. Recently the mechanism of penetratin uptake has been re-evaluated and this led to the conclusion that penetratin translocates primarily by an energy-dependent endocytotic pathway (Richard et al., 2003).

Our results demonstrate that peptide helicity plays no decisive role in penetratin translocation and that the amphiphilicity of the peptide is much more important. Our working hypothesis is that penetratin peptides interact with the cell membrane presumably with electrostatic forces 

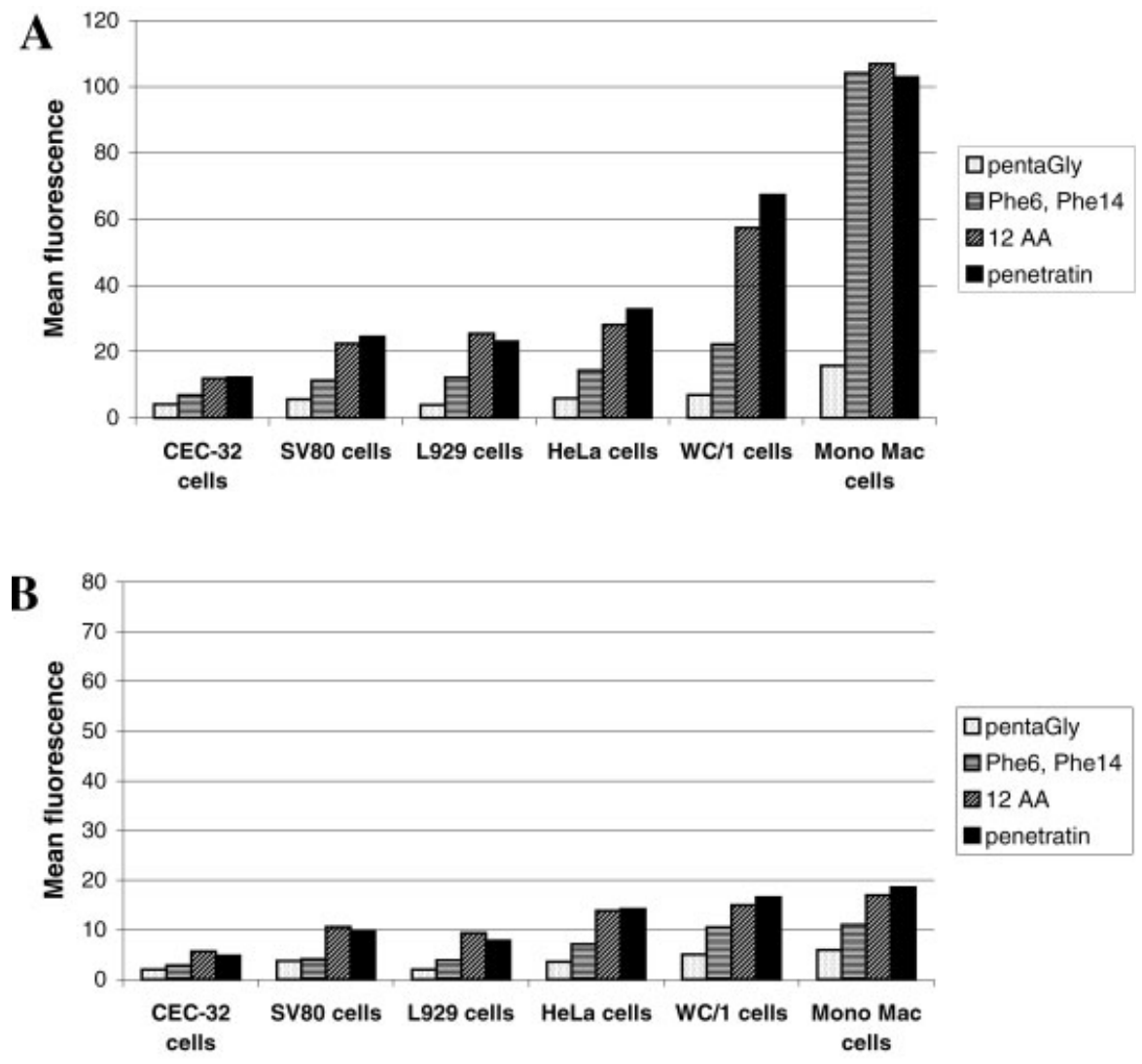

Figure 9. Comparative flow cytometric assay of the cellular uptake of penetratin and its analogs. Various cell-lines (CEC-32, SV80, L929, HeLa, WC/1 and MonoMac) were incubated at $37^{\circ} \mathrm{C}(\mathrm{A})$ and $4^{\circ} \mathrm{C}(\mathrm{B})$ with FITC-labeled penetratin and its analogs at a concentration of $1 \mu \mathrm{M}$ for $60 \mathrm{~min}$. FTC-pentaglycine, a membrane-impermeable peptide, was used as a negative control.

between positively charged Arg/Lys and negatively charged phospholipids. Another important interaction includes the apolar interaction between hydrophobic side chaines and the apolar part of the lipid bilayer. Tryptophans play a crucial role in this interaction and are poorly replaceable by phenylalanine. A conformational change $(\alpha$ helix $\rightarrow \beta$ structure $\rightarrow \alpha$ helix) occurs during membrane translocation. In addition to this direct translocation mechanism, the experiments with MonoMac cells demonstrated that penetratin enters the cell also via an endocytotic pathway.

\section{Acknowledgements}

This study was supported by the National Science Foundation of Hungary (OTKA T030135).

\section{REFERENCES}

Berlose JP, Convert O, Derossi D, Brunissen A, Chassaing G. 1996. Conformational and associative behaviours of the third helix of antennapedia homeodomain in membrane-mimetic environments. Eur. J. Biochem 242: 372-386.

Bogoyevitch MA, Kendrick TS, Ng DCH, Barr RK. 2002. Taking the cell stealth or storm? Protein transduction domains (PTDs) as versatile vectors for delivery. DNA Cell Biol. 21: 879-894.

Brasseur R. 2000. Tilted peptides: a motif for membrane destabilization (hypothesis). Mol. Membrane Biol. 17: 31-40.

Burton PS, Conradi RA, Ho NFH, Hilgers AR, Borchardt RT. 1996. How structural features influence the biomembrane permeability of peptides. J. Pharm. Sci. 85: 1336-1340.

Czajlik A, Meskó E, Penke B, Perczel A. 2002. Investigation of penetratin peptides. Part 1 . The environment dependent conformational properties of penetratin and two of its derivatives. J. Peptide Sci. 8: 151-171.

Derossi D, Joliot AH, Chassaing G, Prochiantz A. 1994. The third helix of the antennapedia homeodomain translocates through biological membranes. J. Biol. Chem. 269: 1044410450.

Derossi D, Calvet S, Trembleau A, Brunissen A, Chassaing G, Prochiantz A. 1996. Cell internalisation of the third helix of the antennapedia homeodomain is receptor-independent. $J$. Biol. Chem. 271: 18188-18193.

Derossi D, Chassaing G, Prochiantz A. 1998. Trojan peptides: the penetratin system for intracellular delivery. Trends Cell Biol. 8: 84-87.

Drin G, Mazel M, Clair P, Mathieu D, Kaczorek M, Temsamani J. 2001. Physico-chemical requirements for cellular uptake of 
pAntp peptide. Role of lipid-binding affinity. Eur. J. Biochem. 268: 1304-1314.

Du C, Yao S, Rojas M, Lin YZ. 1998. Conformational and topological requirements of cell-permeable peptide function. $J$. Peptide Res. 51: 235-243.

Dupont E, Joliot A, Prochiantz A. 2002. Cell Penetrating Peptides, Langel Ü (ed.). CRC Press: Boca Raton, FL; 23-70.

Dyson HJ, Rance M, Houghten RA, Wright PE, Lerner RA. 1988. Folding of immunologenic peptide fragments of proteins in water solution II. The nascent helix. J. Mol. Biol. 201: 201-217.

Fischer PM, Zhelev NZ, Wang S, Melville JE, Fåhraeus R, Lane DP. 2000. Structure-activity relationship of truncated and substituted analogues of the intracellular delivery vector penetratin. J. Peptide Res. 55: 163-172.

Fischer PM, Krausz E, Lane DP. 2001. Cellular delivery of impermeable effector molecules in the form of conjugates with peptides capable of mediating membrane. Bioconjugate Chem. 12: 825-841.

Futaki S, Suzuki T, Ohashi W, Yagami T, Tanaka S, Ueda K, Sugiura Y. 2001. Arginine-rich peptides. An abundant source of membrane-permeable peptides having potential as carriers for intracellular protein delivery. J. Biol. Chem. 276: 5836-5840.

Garcia-Chaumont, Seksek O, Grzybowska J, Borowski E, Bolard J. 2000. Delivery systems for antisense oligonucleotides. Pharmac. Ther. 87: 255-277.

Gariépy J, Kawamura K. 2001. Vectorial delivery of macromolecules into cells using peptide-based vehicles. Trends Biotechnol. 19: 21-28.

Guiochon-Mantel A, Delabre K, Lescop P, Milgrom E. 1994. Nuclear localization signals also mediate the outward movement of proteins from the nucleus. Proc. Natl. Acad. Sci. USA 91: 7179-7183.

Hällbrink M, Florén A, Elmquist A, Pooga M, Bartfai T, Langel Ü. 2001. Cargo delivery kinetics of cell-penetrating peptides. Biochim. Biophys. Acta 78161: 1-9.

Langel Ü (ed.). 2002. Cell Penetrating Peptides. Processes and Applications. CRC Press: Boca Raton, FL; 1-406.

Lin YZ, Yao SY, Veach RA, Torqerson TR, Hawiger J. 1995. Inhibition of nuclear translocation of transcription factor NF-kappa B by a synthetic peptide containing a cell membrane-permeable motif and nuclear localization sequence $J$. Biol. Chem. 270: 14255-14258.

Lindberg M, Gräslund A. 2001. The position of the cell penetrating peptide penetratin in SDS micelles determined by NMR. FEBS Lett. 497: 39-44.

Lindgren M, Hällbrink M, Prochiantz A, Langel Ü. 2000. Cell penetrating peptides. Trends Pharmac. Sci. 21: 99-103.

Magzoub M, Kilk K, Eriksson LEG, Langel Ü, Gräslund A. 2001. Interaction and structure induction of cell-penetraing peptides in the presence of phospholipid vesicles. Biochim. Biophys. Acta 78078: 1-13.

Morris MC, Chaloin L, Mevy J, Heitz F, Divita G. 1999. A novel potent strategy for gene delivery using a single peptide vector as a carrier. Nucleic Acid Res. 27: 3510-3517.

Morris MC, Chaloin L, Heitz F, Divita G. 2000. Translocating peptides and proteins and their use for gene delivery. Curr. Opin. Biotechnol. 11: 461-466.
Oehlke J, Beyermann M, Wiesner B, Melzig M, Berger H, Krause E, Bienert M. 1997. Evidence for extensive and non-specific translocation of oligopeptides across plasma membranes of mammalian cells. Biochim. Biophys. Acta 1330: 50-60.

Oehlke J, Scheller A, Wiesner B, Krause E, Beyermann M, Klauschenz E, Melzig M, Bienert M. 1998. Cellular uptake of an $\alpha$-helical amphipathic model peptide with the potential to deliver polar compounds into the cell interior non-endocytically. Biochim. Biophys. Acta 1414: 127-139.

Persson D, Thorén PEG, Nordén B. 2001. Penetratin-induced aggregation and subsequent dissociation of negatively charged phospholipid vesicles. FEBS Lett. 505: 307-312.

Plank C, Zauner W, Wagner E. 1998. Application of membraneactive peptides for drug and gene delivery across cellular membranes. Adv. Drug Rev. 34: 21-35.

Pooga M, Kut C, Kihlmark M, Raid R, Hällbrink M, Fernaeus SM, Hallberg E, Land T, Langel Ü. 2001. Cellular translocation of proteins by transportan. FASEB J. 15(8): 1451-1453.

Richard JP, Melikov K, Vives E, Ramos C, Verbeure B, Gait MJ, Chernomordik LV, Lebleu B. 2003. Cell-penetrating peptides. A reevaluation of the mechanism of cellular uptake. J. Biol. Chem. 278: 585-590.

Rothbard JB, Garlington S, Lin Q, Kirschberg T, Kreider E, McGrane PL, Wender A, Khavari PA. 2000. Conjugation of arginine oligomers to cyclosporin A facilitates topical delivery and inhibition of inflammation. Nat. Med. 6: 1253-1257.

Rousselle C, Clair P, Lefauconnier JM, Kaczorek M, Scherrmann JM, Temsamani J. 2000. New advances in the transport of doxorubicin through the blood-brain barrier by a peptide vector-mediated strategy. Mol. Pharm. 57: 679-686.

Scheller A, Oehlke J, Wiesner B, Dathe M, Krause E, Beyermann M, Melzig M, Bienert M. 1999. Structural requirements for cellular uptake of $\alpha$-helical amphipathic peptides. J. Peptide Sci. 5: 185-194.

Sheldon K, Liu D, Ferguson J, Gariépy J. 1995. Loligomers: design of de novo peptide-based intracellular vehicles. Proc. Natl Acad. Sci. USA 92: 2056-2060.

Singh D, Bisland SK, Kawamura K, Gariépy J. 1999. Peptidebased intracellular shuttle able to facilitate gene transfer in mammalian cells. Bioconjugate Chem. 10: 745-754.

Suzuki T, Futaki S, Niwa M, Tanaka S, Ueda K, Sugiura Y. 2002. Possible existence of common mechanisms among arginine-rich peptides. J. Biol. Chem. 277: 2437-2443.

Thorén PEG, Persson D, Karlsson M, Nordén B. 2000. The antennapedia peptide penetratin translocates across lipid bilayers - the first direct observation. FEBS Lett. 482: 265268.

Vives E, Brodin P, Lebleu B. 1997. A truncated HIV-1 Tat-protein basic domain rapidly translocates through the plasma membrane and accumulates in the cell nucleus. J. Biol. Chem. 272: 16010-16017.

Wender PA, Mitchell DJ, Pattabiraman K, Pelkey ET, Steinman L. 2000. The design, synthesis, and evaluation of molecules that enable or enhance cellular uptake: peptoid molecular transporters. Proc. Natl Acad. Sci. USA 97: 13003-13008.

Zhang L, Torqerson TR, Lin XY, Timmons S, Colosia AD, Hawiger J. 1998. Preparation of functionally active cell-permeable peptides by single-step ligation of two peptide modules. Proc. Natl Acad. Sci. USA 95: 9184-9189. 